\title{
Emission of Air Pollution in the Transport Sector: Case Study of the City of Campos dos Goytacazes, Brazil
}

\author{
Marcenilda A. Lima, Marcelo S. Sthel* \\ Laboratory of Physical Sciences, Center of Science and Technology, State University of Northern Fluminense, \\ Campos dos Goytacazes, Brazil \\ Email: marcenilda_stm@yahoo.com.br, *sthel@uenf.br
}

How to cite this paper: Lima, M.A. and Sthel, M.S. (2020) Emission of Air Pollution in the Transport Sector: Case Study of the City of Campos dos Goytacazes, Brazil. Engineering, 12, 851-862.

https://doi.org/10.4236/eng.2020.1212060

Received: October 26, 2020

Accepted: December 6, 2020

Published: December 9, 2020

Copyright $\odot 2020$ by author(s) and Scientific Research Publishing Inc. This work is licensed under the Creative Commons Attribution International License (CC BY 4.0).

http://creativecommons.org/licenses/by/4.0/

\section{(c) (i) Open Access}

\begin{abstract}
The transportation sector is certainly one of the main agent's principals and has contributed to the increase in global air pollution. In Brazil, the large-scale use of diesel for charge and passenger transport produces considerable air pollution in cities. The objectives of the study were to determine the concentrations of gas emissions $\left(\mathrm{CO}, \mathrm{NO}\right.$ and $\left.\mathrm{NO}_{2}\right)$, identify the chemical species that make up the particulates, from the exhaust of diesel vehicles and identify chemical species of particulates accumulated in air conditioning filters realized in the city of Campos dos Goytacazes located in the State of Rio de Janeiro. Thus, for the determination of the gas concentrations, electrochemical sensors were used and in the identification of chemical species, X-ray fluorescence spectroscopy was used. The results showed $\mathrm{CO}$ concentrations in the range of 173 to $880 \mathrm{ppmv}$, of $\mathrm{NO}$ in the range 52 to $240 \mathrm{ppmv}$ and $\mathrm{NO}_{2}$ in the range 6 to $252 \mathrm{ppmv}$ in the vehicles exhaust, and chemical species of the particulates in the exhaust identified: $\mathrm{Ca}, \mathrm{Si}, \mathrm{Fe}, \mathrm{S}, \mathrm{Ti}, \mathrm{P}, \mathrm{Zn}, \mathrm{Sc}$ and $\mathrm{Mn}$. Furthermore, $\mathrm{Ca}, \mathrm{Si}, \mathrm{Fe}, \mathrm{S}, \mathrm{Ti}, \mathrm{P}, \mathrm{Zn}, \mathrm{Mn}, \mathrm{K}, \mathrm{Cl}, \mathrm{Al}, \mathrm{Pb}, \mathrm{V}, \mathrm{Cu}, \mathrm{Sr}, \mathrm{Br}$ and Er were in the air conditioning system. The concentration of gases and particulates is increased by the presence of a large highway that runs through the city, with one intense flow of trucks and buses, which certainly contributes to the reduction of the region's air quality.
\end{abstract}

\section{Keywords}

Vehicles, Air Pollution, Emissions, Particulates

\section{Introduction}

Air pollution has become one of the most serious environmental problems to- 
day, generating several atmospheric phenomena, such as: acid rain, photochemical smog, ozone layer destruction and climate change [1] [2] [3] [4] [5]. The presence of toxic contaminants in the atmosphere causes serious damage to human health [6].

The transport sector is one of the main polluters of the environment world level [7] [8] [9] [10]. This sector has been using fossil fuels intensively since the industrial revolution, contributing to the increase in greenhouse gas emissions [1].

In the urban areas, gaseous emissions from diesel vehicles and particulate matter are considered highly toxic pollutants, causing respiratory, cardiovascular or allergic diseases, intracerebral hemorrhage and cancer [11]-[17]. This can be found in human brains [18]. Therefore, there is a concern to identify these chemical sources and species, as well as to monitor and reduce them, mainly in large urban centers.

In the Traffic Department of the State of Rio de Janeiro (DETRAN/RJ), until February 2020, there were 15,187 diesel vehicles registered in Campos dos Goytacazes. Moreover, this has increased over the years in the city and across the country. Another worrying factor is related to the average age of these vehicles: most of them have more than 20 years of use. The discarded fleet increases pollutant emissions due to the poor maintenance conditions of these vehicles [19].

There is an increase in demand for reliable sensors for continuous online, in situ and real-time monitoring of gaseous species in environmental and industrial processes. Those have been used in several research areas [20], as in the detection of emissions of trace gases $\left(\mathrm{CO}, \mathrm{NO}_{\mathrm{x}}\right.$ and $\left.\mathrm{SO}_{2}\right)$ from diesel engines [21] and vehicles powered by ethanol and gasoline [22], indoor air quality (detection of toxic gases, such as benzene, toluene and methane) [23], agriculture $\left(\mathrm{NH}_{3}\right.$ and $\mathrm{NO}_{2}$ ) and environmental monitoring of greenhouse gases greenhouse [24] [25]. In addition, studies have also been carried out of nitrogen dioxide $\left(\mathrm{NO}_{2}\right)$ and sulfur dioxide $\left(\mathrm{SO}_{2}\right)$ present in air pollution, emitted from diesel-powered vehicles in the city of Campos dos Goytacazes [8].

The objective of this work is the detection of pollutant gas emissions (CO, NO and $\mathrm{NO}_{2}$ ), and the identification of chemical species constituting particulate material from combustion in automotive engines and of air conditioning filters and moreover, also to identify the influence of the federal highway that cuts through the city of Campos dos Goytacazes. The use of electrochemical sensors makes it possible to obtain the concentrations in the ppmv range of exhaust from city vehicles. The identification of the different chemical species constituents in the particulates is realized by X-ray fluorescence spectroscopy.

\section{Methodology}

\subsection{Location of the Study Area (City of the Campos dos Goytacazes/Rio de Janeiro)}

Campos dos Goytacazes is a city in the interior of the State of Rio de Janeiro (Figure 1(a)), Southeastern region of the country. This city is located in the North- 
ern Fluminense region of the state (Figure 1(b)), and according to the Brazilian Institute of Geography and Statistics [26], has an estimated population of more than 500 thousand inhabitants, being the seventh most populous in the interior of the state. The city has a larger territorial extension, occupying an area of $4032.5 \mathrm{~km}^{2}$.

On its coast is the largest oil platform in Brazil, the P-51 in the Campos basin, making the city together with Macaé the title of National Petroleum Capital. As the pole city of the Northern Fluminense region, Campos works as a dormitory city for workers in Porto do Açu, the largest port-industry enterprise in Latin America.

The study of particulate samples and detection of carbon monoxide (CO), nitrogen oxide (NO) and nitrogen dioxide $\left(\mathrm{NO}_{2}\right)$ gases were carried out in Campos dos Goytacazes. The particulates were obtained from air conditioning filters for each season of the year, in the Flamboyant neighborhood and the gases were detected by an electrochemical analyzer, directly from the exhaust system of automotive vehicles that circulate the city.

\subsection{Pollutant Gas Analyzer}

The experimental procedure used to detect carbon monoxide (CO), nitrogen oxide $(\mathrm{NO})$ and nitrogen dioxide $\left(\mathrm{NO}_{2}\right)$ gases was the electrochemical analyzer model Testo 350-XL (Figure 2). To carry out the emission measurements, the Testo 350-XL analyzer is connected directly to the exhaust system (exhaust) of automotive vehicles (buses, trucks and cars), through a probe that transport the gases to the detection cells inside the device. This probe is approximately 1.5 meters long, capable of withstanding temperatures up to $700^{\circ} \mathrm{C}$. The vehicles were chosen at random in order to reproduce the real traffic conditions, being the truck and car traveling along the federal highway BR-101 that crosses the city and the bus used in public transportation within the Campos dos Goytacazes perimeter.

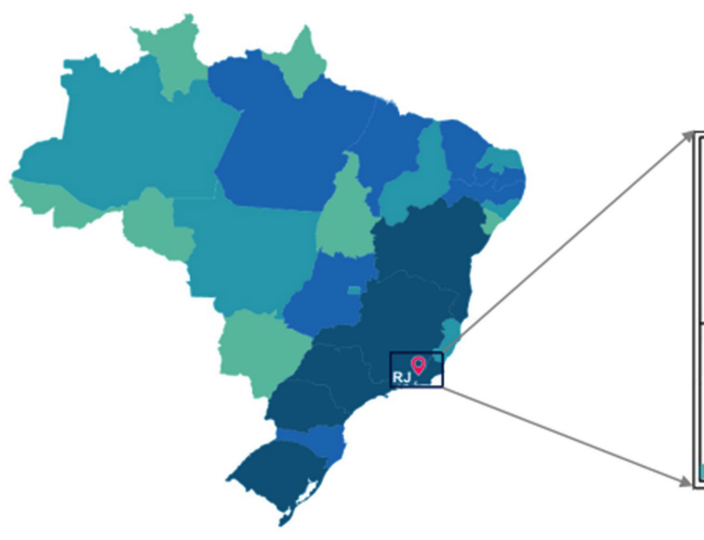

(a)

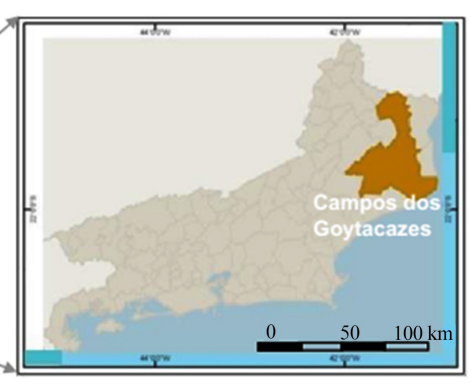

(b)

Figure 1. (a) Map indicating the State of Rio de Janeiro; (b) Location of the study area in the city of Campos dos Goytacazes. 


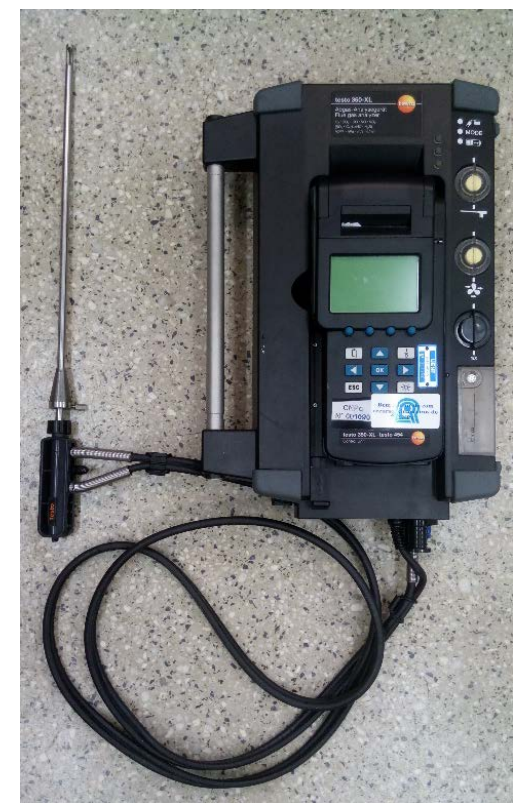

Figure 2. Testo 350-XL electrochemical analyzer for detection of $\mathrm{CO}, \mathrm{NO}$ and $\mathrm{NO}_{2}$.

The Testo 350-XL portable analyzer is a portable device consisting of electrochemical sensors (Citycell Gold Class) capable of simultaneously detecting, by means of a distributor system, the concentration of carbon monoxide (0 to 10,000 ppmv), nitrogen oxides ( 0 at $3000 \mathrm{ppmv}$ ) and nitrogen dioxide (0 to 500 ppmv) emitted in the environment. The detection of the emitted gases occurred in two modes of engine operation, low speed $(800 \mathrm{rpm})$ and high speed (1500 $\mathrm{rpm})$. The measurements were carried out for 3 minutes, with regular intervals of 5 minutes to stabilize the engine.

\subsection{Collection and Analysis of Particulate Materials}

The collections of the samples of particulate material were carried out in air conditioning filters, installed in the Flamboyant neighborhood. Figure 3 shows the materials collected for each season from year $12 / 2017$ to $03 / 2019$. There is a variation in the shade of the samples for different periods analyzed. These samplings allow the identification of particulate matter from different sources of pollution in the city.

The collection of exhaust samples from automotive engines was carried out by scrape accumulated material from the combustion in the vehicles exhaust system. The samples obtained from the particulates were dried at a temperature of $100^{\circ} \mathrm{C}$. Thus, after this step, the samples were taken to the Shimadzu X-ray fluorescence EDS-XRF spectrometer to complete characterization. This technique made it possible to identify the chemical species that constitute up the particulate material from vehicle exhaustion, and other sources of pollution in the city, such as: cane burn, civil construction and the industrial sector (ceramics), for the case of samples collected of the air conditioning filter. 


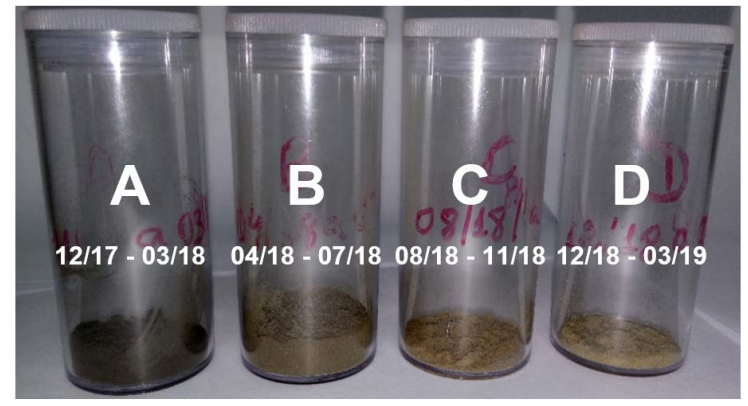

Figure 3. Samples collected in the air conditioning filters, referring to each season of the year, in the period of $12 / 2017$ at $03 / 2019$.

\section{Results and Discussions}

\subsection{Gaseous Emissions (Detection of $\mathrm{CO}, \mathrm{NO}$ and $\mathrm{NO}_{2}$ )}

The results of this research corroborate with data obtained in researches carried out in Campos dos Goytacazes by Geórgia et al. [8], Geórgia et al. [21]; and Carla et al. [27]. Therefore, this makes it possible to assess that the gaseous emissions from combustion in automotive vehicles still show a pattern of possible polluting gases in the ppmv range, which depending on the type of vehicle and year influence the variations in emissions. This experiment aimed to reproduce the dynamics of real traffic in a city. Therefore, the choice of vehicles was random, in order to check the gases present in situ, without the need to standardize the vehicles. Table 1 shows the results obtained from $\mathrm{CO}, \mathrm{NO}$ and $\mathrm{NO}_{2}$ emissions expressed in average values, quantified by the Testo $350 \mathrm{XL}$ analyzer.

According to Table 1, the CO concentrations show that they were high for Toyota 2.5 in both the low rotation and high rotation modes, since it is an old model, it still did not have filters. Furthermore, the $\mathrm{CO}$ emission is higher in the low rotation mode than in the high rotation mode, as the combustion temperature is lower, and there is a higher incidence of incomplete combustion, generating greater amount of carbon monoxide. It is observed that for low and high engine rotation modes, the truck obtained higher concentrations of $\mathrm{NO}$, and the Mercedes bus showed higher concentrations of $\mathrm{NO}_{2}$. This is probably associated with the operating system, type, model and year of each vehicle analyzed.

This experiment allowed to reproduce the dynamics of the real traffic of vehicles traveling in Campos dos Goytacazes. Therefore, the choice of vehicles was random, in order to check the gases present in situ (in the city), without the need to standardize the vehicles. Thus, it is observed that each type of vehicle has a different gas concentration emission.

In order to obtain an effective assessment of the emissions of polluting gases and particulate matter from combustion in automotive engines in the city of Campos do Goytacazes, it is necessary to know the number of vehicles that travel daily in the city. According to statistical data from the company Arteris Fluminense that operates on BR 101, there is a daily traffic of approximately 110 thousand vehicles, part of this traffic and of the federal highway that cuts through the city, contributes to the increase in atmospheric pollution. 
Table 1. Gaseous emissions of $\mathrm{CO}, \mathrm{NO}$ and $\mathrm{NO}_{2}$ from the exhaust of different types of automotive engines.

\begin{tabular}{|c|c|c|c|c|c|c|}
\hline \multirow{2}{*}{ Vehicle } & \multirow{2}{*}{ Type } & \multirow{2}{*}{ Model } & \multirow{2}{*}{ Year } & \multicolumn{3}{|c|}{ Low and High Rotation (ppmv) } \\
\hline & & & & $\mathrm{CO}$ & NO & $\mathrm{NO}_{2}$ \\
\hline \multirow{2}{*}{1} & \multirow{2}{*}{ Van } & \multirow{2}{*}{ Peugeot boxer 2.3} & \multirow{2}{*}{2010} & 173 & 119 & 8.6 \\
\hline & & & & 235 & 141 & 16.8 \\
\hline \multirow{2}{*}{2} & \multirow{2}{*}{ Truck } & \multirow{2}{*}{ Agrale 8500} & \multirow{2}{*}{2010} & 236 & 240 & 20.0 \\
\hline & & & & 177 & 230 & 27.6 \\
\hline \multirow{2}{*}{3} & \multirow{2}{*}{ Bus } & \multirow{2}{*}{ Volkswagen } & \multirow{2}{*}{2009} & 211 & 134 & 13.4 \\
\hline & & & & 234 & 67 & 14.4 \\
\hline \multirow{2}{*}{4} & \multirow{2}{*}{ Bus } & \multirow{2}{*}{ Mercedes } & \multirow{2}{*}{2006} & 224 & 147 & 246 \\
\hline & & & & 246 & 128 & 252 \\
\hline \multirow{2}{*}{5} & \multirow{2}{*}{ Minibus } & \multirow{2}{*}{ Iveco } & \multirow{2}{*}{2003} & 190 & 116 & 6.0 \\
\hline & & & & 223 & 52 & 8.0 \\
\hline \multirow{2}{*}{6} & \multirow{2}{*}{ Pickup Truck } & \multirow{2}{*}{ Toyota 2.5} & \multirow{2}{*}{1997} & 880 & 71 & 54.3 \\
\hline & & & & 640 & 91 & 58.9 \\
\hline
\end{tabular}

The company Autopista Arteris Fluminense S/A is responsible for 320 kilometers of the BR-101 RJ/Norte highway, corresponding to the stretch that connects the city of Niterói to Campos dos Goytacazes, bordering the state of Espírito Santo, Ponte Presidente Costa and Silva. Thus, it was hired and began a concession on February 18, 2008, developing a service for a period of 25 years. Therefore, regarding the section managed by the company, BR-101/RJ connects the cities of Campos dos Goytacazes, Conceição de Macabu, Quissamã, Carapebus, Macaé, Rio das Ostras, Casimiro de Abreu, Silva Jardim, Rio Bonito, Tanguá, Itaboraí , São Gonçalo and Niterói.

The Brazilian road network plays an important role from an economic point of view, connecting the northern coast of the State of Rio de Janeiro and its oil basins. Moreover, it allows access to a region of tourist hubs, such as Búzios, Cabo Frio and the southern coast of Capixaba. The movement is registered in Avenida do Contorno, in Niterói, with about 100 thousand vehicles. In the region of Silva Jardim, Casimiro de Abreu and Macaé, the average daily traffic volume is 15 thousand vehicles. In the section near the border with the State of Espírito Santo, the average daily traffic volume is six thousand vehicles.

The investments and works applied in infrastructure made by Arteris in ten years of concession, completed in February 2018, transformed the BR-101 into a safe highway. In recent years, Arteris Fluminense has registered improvements in the main road safety indicators. As the greatest example of this effort, the concessionaire has already surpassed, with two years in advance, the UN target for the Decade of Action for Traffic Safety, which establishes a reduction in accidents with victims in half. The highway voluntarily adhered to the goal and has already reduced casualties by 58\% between 2011 and 2017 .

Figure 4 shows the section that approximately corresponds to the future contour that the company Arteris intends to build in a way that reduces the distance around $23 \mathrm{~km}$ (continuous green line). Therefore, aims to improve the traffic of vehicles, and also to reduce the levels of atmospheric pollution that they emit 


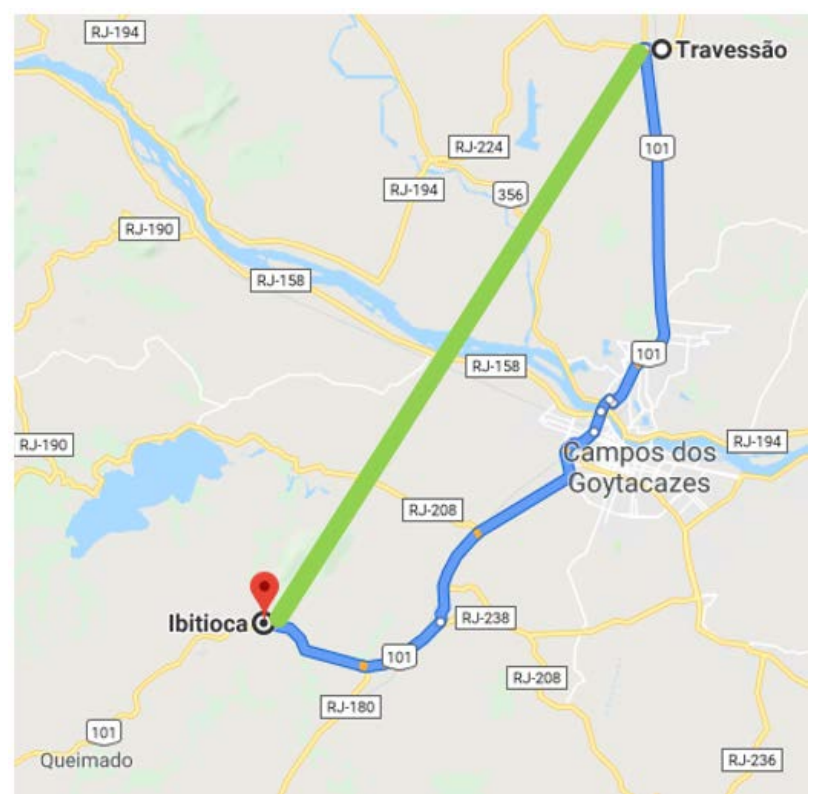

Figure 4. Section corresponding to the contour that the company Arteris intends to build to reduce the distance around $23 \mathrm{~km}$. Source: [28].

daily. The section in blue corresponds to the current direction of the current flow of traffic on BR 101 which runs through the city of Campos dos Goytacazes, leaving Ibitioca to the Travessão neighborhood $(38.1 \mathrm{~km})$.

\subsection{Analysis of Particulate Materials}

The results in Table 2 show identification of the chemical species that make up the particulate material generated by the combustion of diesel engines (minibuse and truck) that travel in Campos, a region where the BR 101 highway crosses the city. The emission of particulate material into the environment is related to the burning of diesel oil, lubricating oil and wear on the bearings and engine materials. Therefore, initially the characterization of the samples of particles collected by filters in the Flamboyant neighborhood in Campos dos Goytacazes was carried out. The X-ray fluorescence technique was used to identify the chemical species that make up this particulate material. Thus, with the analysis of the results, it was possible to identify the possible sources of its origin, such as: burning of cane, civil construction or transportation sector (fossil fuels), which is one of the objectives of this study. The following elements presented in Table 2 and Table 3 were identified with this technique, which corresponds to the percentage of some elements that form its composition.

Table 3 shows the elements obtained from the air conditioning filters. According to [29] the chemical composition of the particulate material is due to the composition of the dust coming from the roads in urban and industrial areas.

Thus, roadside industrial dust is associated with elements potentially toxic to humans, where it contains elements of $\mathrm{Fe}, \mathrm{Ni}, \mathrm{Cu}, \mathrm{Ti}, \mathrm{V}, \mathrm{Pb}, \mathrm{Ba}, \mathrm{Sb}, \mathrm{Cr}, \mathrm{Sn}, \mathrm{Pb}$, As and $\mathrm{Ga}$. Contamination in urban areas may contain $\mathrm{Cu}, \mathrm{Zn}, \mathrm{Sb}, \mathrm{Ga}, \mathrm{As}$ and $\mathrm{Pb}$. 
Table 2. Samples of particulates from the Minibus and Truck exhaust for X-ray fluorescence analysis.

\begin{tabular}{ccc}
\hline \multirow{2}{*}{ Elements } & \multicolumn{2}{c}{ Concentrations of particulate (\%) } \\
\cline { 2 - 3 } & Minibus & Truck \\
\hline $\mathrm{Fe}$ & 52.805 & 65.236 \\
$\mathrm{Ca}$ & 18.562 & 9.859 \\
$\mathrm{~S}$ & 12.403 & 8.886 \\
$\mathrm{Zn}$ & 6.005 & 9.817 \\
$\mathrm{P}$ & 4.795 & 2.417 \\
$\mathrm{Si}$ & 4.152 & 2.692 \\
$\mathrm{Sc}$ & 0.646 & 0.000 \\
$\mathrm{Ti}$ & 0.632 & 0.496 \\
$\mathrm{Mn}$ & 0.000 & 0.597 \\
\hline
\end{tabular}

Table 3. Particulate samples collected from filters in the Flamboyant neighborhood in Campos dos Goytacazes, referring to each season of the year in the period of 12/2017 and 03/2019.

\begin{tabular}{|c|c|c|c|c|}
\hline \multirow{2}{*}{ Elements } & \multicolumn{4}{|c|}{ Concentrations of particulate (\%) } \\
\hline & A & B & $\mathrm{C}$ & $\mathrm{D}$ \\
\hline $\mathrm{Ca}$ & 37.348 & 36.348 & 39.504 & 31.194 \\
\hline $\mathrm{K}$ & 20.075 & 21.993 & 19.563 & 26.247 \\
\hline $\mathrm{Cl}$ & 16.113 & 15.332 & 19.137 & 20.329 \\
\hline $\mathrm{Si}$ & 7.084 & 8.813 & 4.481 & 5.272 \\
\hline $\mathrm{Fe}$ & 5.635 & 5.001 & 5.084 & 4.864 \\
\hline S & 5.565 & 5.254 & 6.402 & 6.990 \\
\hline $\mathrm{Ti}$ & 4.106 & 2.974 & 2.652 & 2.286 \\
\hline $\mathrm{Al}$ & 1.969 & 2.849 & 1.663 & 1.955 \\
\hline $\mathrm{P}$ & 0.525 & 0.000 & 0.762 & 0.399 \\
\hline $\mathrm{Zn}$ & 0.519 & 0.645 & 0.382 & 0.364 \\
\hline $\mathrm{Pb}$ & 0.342 & 0.000 & 0.000 & 0.000 \\
\hline $\mathrm{Mn}$ & 0.272 & 0.301 & 0.273 & 0.000 \\
\hline $\mathrm{V}$ & 0.196 & 0.095 & 0.000 & 0.000 \\
\hline $\mathrm{Cu}$ & 0.167 & 0.160 & 0.127 & 0.091 \\
\hline $\mathrm{Br}$ & 0.048 & 0.000 & 0.000 & 0.000 \\
\hline $\mathrm{Sr}$ & 0.036 & 0.044 & 0.000 & 0.000 \\
\hline Er & 0.000 & 0.192 & 0.000 & 0.000 \\
\hline
\end{tabular}

It is observed that the elements of $\mathrm{Cl}$ and $\mathrm{K}$ present in the particulate samples collected from filters (Table 3) do not appear in the vehicle exhaust (Table 2), since $\mathrm{Cl}$ comes from maritime regions, in which this element can be transported 
by breezes from São João da Barra beach in Atafona, which is about $36 \mathrm{~km}$ from Campos dos Goytacazes. The element chemical $\mathrm{K}$ is generated by burning sugarcane straw as shown in the research by [30] in which they obtained for $\mathrm{K}$ the percentage relative of $18.58 \%$ to the total of analyzed elements. In addition, it was also noted that virtually all elements found in vehicle exhaust (Table 2) are in the air conditioning filter (Table 3 ). This result was evident in the air conditioning filter, as it involves the particles generated by transport in traffic and the burning of sugarcane. Therefore, the sector transport and the burning of sugarcane are important sources of pollution and particulate emissions in the city.

Second [8] elements such as $\mathrm{Zn}$ and $\mathrm{Cu}$ are probably caused by the degradation of structural metal parts of the engine and are harmful to humans. The Mn and Fe elements are probably derived from the internal corrosion process of the stainless steel components. Si elements can be derived from possible contamination of the sample with environmental dust. The $\mathrm{P}$ residues may come from the contamination of detergent and lubricant additives, while $\mathrm{K}$ and $\mathrm{Ca}$ may be residues from catalysts, such as $\mathrm{KOH}$ and $\mathrm{CaOH}$, respectively [8].

According research of [31], it presents results of the elemental composition of sugarcane straw ashes as a percentage of oxides, and there was a predominance of silica $\left(\mathrm{SiO}_{2}-45.49 \%\right)$, aluminum oxide (Alumina- $\left.\mathrm{Al}_{2} \mathrm{O}_{3}-10.59 \%\right)$, ferric oxide (hematite $-\mathrm{Fe}_{2} \mathrm{O}_{3}-3.95 \%$ ) and titanium dioxide (Titânia- $\mathrm{TiO}_{2}-0.66 \%$ ). These components can be considered as impurities in planting and mechanized harvesting, due to contact with the soil and a low percentage in isolated biomasses. The particulate samples collected from filters in the Flamboyant neighborhood in Campos dos Goytacazes (Table 3) showed the presence of the chemical elements $\mathrm{Si}, \mathrm{K}, \mathrm{Ca}, \mathrm{Al}, \mathrm{Fe}, \mathrm{P}, \mathrm{S}, \mathrm{Ti}, \mathrm{Cl}, \mathrm{Mn}$ that are consistent with the elements obtained [31].

\section{Conclusions}

With the methodology used in this work, it was possible to identify and determine the concentrations in the ppmv range of gaseous molecules of environmental interest $\mathrm{CO}, \mathrm{NO}$ and $\mathrm{NO}_{2}$ from the exhaust of different types of automotive engines, and also the identification of the chemical composition of the particulate samples of the truck and minibus exhaust. The particles collected from filters in the Flamboyant neighborhood in Campos dos Goytacazes are originated by several sources located in the city. The X-ray fluorescence technique was able to identify the chemical species that make up the particulates, composed of the following elements: $\mathrm{Ca}, \mathrm{K}, \mathrm{Cl}, \mathrm{Si}, \mathrm{Fe}, \mathrm{S}, \mathrm{Ti}, \mathrm{Al}, \mathrm{P}, \mathrm{Zn}, \mathrm{Pb}, \mathrm{Mn}, \mathrm{V}, \mathrm{Cu}$, $\mathrm{Br}$, Sr. These species come from the burning of diesel in the transport sector, the wear of engine parts, construction, the burning of sugar cane and sea breezes.

This research contributes to the alert about the environmental consequences for the city, mainly with regard to the health of the local population. Thus, assessing emissions of polluting gases and particulate matter from combustion in automotive engines is of great relevance for public managers in the region. The 
construction of a contour to remove the highway that cuts through the city is an essential factor for reducing pollution, being strongly recommended by the authors of this research.

\section{Acknowledgements}

The authors are grateful to the Brazilian agencies of the Foundation for Research Support of the State of Rio de Janeiro (FAPERJ), National Council for Scientific and Technological Development (CNPq), Coordination of Improvement of Higher Education Personnel (CAPES) for the financial support.

\section{Conflicts of Interest}

The authors declare no conflicts of interest regarding the publication of this paper.

\section{References}

[1] Intergovernmental Panel on Climate Change (2013) Climate Change 2013: The Physical Science Basics. In: Stocker, T.F., Qin, D., Plattner, G.-K., Tignor, M., Allen, S.K., Boschung, J., Nauels, A., Xia, Y., Bex, V. and Midgley, P.M., Eds., Contribution of Working Group I to the Fifth Assessment Report of the Intergovernmental Panel on Climate Change, Cambridge University Press, Cambridge, New York, 1535 p.

[2] Silva, R.A., West, J.J., Lamarque, J.F., Shindell, D.T., Collins, W.J., Faluvegi, G., Rumbold, S.T., et al. (2017) Future Global Mortality from Changes in Air Pollution Attributable to Climate Change. Nature Climate Change, 7, 647-651. https://doi.org/10.1038/nclimate3354

[3] Hansen, J., Sato, M., Kharecha, P., Schuckmann, K.V., Beerling, D.J., Cao, J. and Shakun, J. (2017) Young People's Burden: Requirement of Negative $\mathrm{CO}_{2}$ Emissions. Earth System Dynamics, 8, 577-616. https://doi.org/10.5194/esd-8-577-2017

[4] Wang, H.J. (2018) On Assessing Haze Attribution and Control Measures in China. Atmospheric and Oceanic Science Letters, 11, 120-122. https://doi.org/10.1080/16742834.2018.1409067

[5] Ault, T.R. (2020) On the Essentials of Drought in a Changing Climate. Science, 368, 256-260. https://doi.org/10.1126/science.aaz5492

[6] Mofijur, M., Rasul, M.G., Hyde, J., Azad, A.K., Mamat, R. and Bhuiya, M.M.K. (2016) Role of Biofuel and Their Binary (Diesel-Biodiesel) and Ternary (Ethanol-Biodiesel-Diesel) Blends on Internal Combustion Engines Emission Reduction. Renewable and Sustainable Energy Reviews, 53, 265-278.

https://doi.org/10.1016/j.rser.2015.08.046

[7] Fuglestvedt, J.S., Shine, K.P., Berntsen, T., Cook, J., Lee, D.S., Stenke, A. and Waitz, I.A. (2010) Transport Impacts on Atmosphere and Climate: Metrics. Atmospheric Environment, 44, 4648-4677. https://doi.org/10.1016/j.atmosenv.2009.04.044

[8] Mothé, G.A., Sthel, M.S., de Castro, M.P.P., Toledo, R., Stumbo, A., Gomes, M., Esquef, I. and Vargas, H. (2014) Air Pollution in the Brazilian Road Transport and Its Environmental and Social Consequences. Journal of Environmental Protection, 5, 1466-1476. http://dx.doi.org/10.4236/jep.2014.515139

[9] Grigoratos, T., Fontaras, G., Giechaskiel, B. and Zacharof, N. (2019) Real World Emissions Performance of Heavy-Duty Euro VI Diesel Vehicles. Atmospheric Environment, 201, 348-359. https://doi.org/10.1016/j.atmosenv.2018.12.042 
[10] Yang, S. and Lee, C. (2019) Exhaust Gas Characteristics According to the Injection Conditions in Diesel and DME Engines. Applied Sciences, 9, 647. https://doi.org/10.3390/app9040647

[11] Mansha, M., Ghauri, B., Rahman, S. and Amman, A. (2012) Characterization and Source Apportionment of Ambient Air Particulate Matter $\left(\mathrm{PM}_{2.5}\right)$ in Karachi. Science of the Total Environment, 425, 176-183. https://doi.org/10.1016/j.scitotenv.2011.10.056

[12] Kim, Y.H., Kim, K.H., Ma, C.J., Shon, Z.H., Park, C.G., Song, S.K. and Brown, R.J. (2014) An Investigation into the Relationship between the Major Chemical Components of Particulate Matter in Urban Air. Chemosphere, 95, 387-394. https://doi.org/10.1016/j.chemosphere.2013.09.050

[13] Gilardoni, S., Massoli, P., Paglione, M., Giulianelli, L., Carbone, C., Rinaldi, M., et al. (2016) Direct Observation of Aqueous Secondary Organic Aerosol from Biomass-Burning Emissions. Proceedings of the National Academy of Sciences of the United States of America, 113, 10013-10018. https://doi.org/10.1073/pnas.1602212113

[14] Maji, K.J., Dikshit, A.K., Arora, M. and Deshpande, A. (2018) Estimating Premature Mortality Attributable to $\mathrm{PM}_{2.5}$ Exposure and Benefit of Air Pollution Control Policies in China for 2020. Science of the Total Environment, 612, 683-693. https://doi.org/10.1016/j.scitotenv.2017.08.254

[15] Nzwalo, H., Guilherme, P., Nogueira, J., Félix, C., André, A., Teles, J., et al. (2019) Fine Particulate Air Pollution and Occurrence of Spontaneous Intracerebral Hemorrhage in an Area of Low Air Pollution. Clinical Neurology and Neurosurgery, 176, 67-72. https://doi.org/10.1016/j.clineuro.2018.11.022

[16] Tsai, D.H., Riediker, M., Berchet, A., Paccaud, F., Waeber, G., Vollenweider, P. and Bochud, M. (2019) Effects of Short- and Long-Term Exposures to Particulate Matter on Inflammatory Marker Levels in the General Population. Environmental Science and Pollution Research, 26, 19697-19704. https://doi.org/10.1007/s11356-019-05194-y

[17] Bi, C.L., Chen, Y.T., Zhao, Z.Z., Li, Q., Zhou, Q.F., Ye, Z.L. and Ge, X.L. (2020) Characteristics, Sources and Health Risks of Toxic Species (PCDD/Fs, PAHs and Heavy Metals) in $\mathrm{PM}_{2.5}$ during Fall and Winter in an Industrial Area. Chemosphere, 238, Article ID: 124620. https://doi.org/10.1016/j.chemosphere.2019.124620

[18] Maher, B.A., Ahmed, I.A., Karloukovski, V., MacLaren, D.A., Foulds, P.G., Allsop, D., Calderon-Garciduenas, L., et al. (2016) Magnetite Pollution Nanoparticles in the Human Brain. Proceedings of the National Academy of Sciences of the United States of America, 113, 10797-10801. https://doi.org/10.1073/pnas.1605941113

[19] Detran Departamento Estadual de Trânsito (2020). http://www.detran.rj.gov.br/

[20] Liu, X., Cheng, S., Liu, H., Hu, S., Zhang, D. and Ning, H. (2012) A Survey on Gas Sensing Technology. Sensors, 12, 9635-9665. https://doi.org/10.3390/s120709635

[21] Mothé, G., Castro, M., Sthel, M., Lima, G., Brasil, L., Campos, L., Rocha, A. and Vargas, H. (2010) Detection of Greenhouse Gas Precursors from Diesel Engines Using Electrochemical and Photoacoustic Sensors. Sensors, 10, 9726-9741.

https://doi.org/10.3390/s101109726

[22] Tavares, J.R., Sthel, M.S., Campos, L.S., Rocha, M.V., Lima, G.R., Da Silva, M.G. and Vargas, H. (2011) Evaluation of Pollutant Gases Emitted by Ethanol and Gasoline Powered Vehicles. Procedia Environmental Sciences, 4, 51-60. https://doi.org/10.1016/j.proenv.2011.03.007

[23] Ariga, K., Ishihara, S., Abe, H., Li, M. and Hill, J.P. (2012) Materials Nanoarchitec- 
tonics for Environmental Remediation and Sensing. Journal of Materials Chemistry, 22, 2369-2377. https://doi.org/10.1039/C1JM14101E

[24] Neethirajan, S., Jayas, D.S. and Sadistap, S. (2009) Carbon Dioxide $\left(\mathrm{CO}_{2}\right)$ Sensors for the Agri-Food Industry-A Review. Food and Bioprocess Technology, 2, 115-121. https://doi.org/10.1007/s11947-008-0154-y

[25] Zimmer, M., Erzinger, J., Kujawa, C. and Group, C. S. (2011) The Gas Membrane Sensor (GMS): A New Method for Gas Measurements in Deep Boreholes Applied at the $\mathrm{CO}_{2}$ SINK Site. International Journal of Greenhouse Gas Control, 5, 995-1001. https://doi.org/10.1016/j.ijggc.2010.11.007

[26] Instituto Brasileiro de Geografia e Estatística (2014) Amazonia Legal. https://www.ibge.gov.br/geociencias/cartas-e-mapas/mapas-regionais/15819-amazo nia-legal.html?=\&t=0-que-e

[27] Teodoro, C.G., Schramm, D.U., Sthel, M.S., Lima, G.R., Rocha, M.V., Tavares, J.R. and Vargas, H. (2010) $\mathrm{CO}_{2}$ Laser Photoacoustic Detection of Ethylene Emitted by Diesel Engines Used in Urban Public Transports. Infrared Physics \& Technology, 53, 151-155. https://doi.org/10.1016/j.infrared.2009.10.009

[28] Google Maps (2020). https://www.google.com/maps/place/Campos+dos+Goytacazes

[29] Ali, M.U., Liu, G., Yousaf, B., Abbas, Q., Ullah, H., Munir, M.A.M. and Fu, B. (2017) Pollution Characteristics and Human Health Risks of Potentially (Eco) Toxic Elements (PTEs) in Road Dust from Metropolitan Area of Hefei, China. Chemosphere, 181, 111-121. https://doi.org/10.1016/j.chemosphere.2017.04.061

[30] Sthel, M.S., Mothé G.A., Lima, M.A., de Castro, M.P., Esquef, I. and da Silva, M.G. (2019) Pollutant Gas and Particulate Material Emissions in Ethanol Production in Brazil: Social and Environmental Impacts. Environmental Science and Pollution Research, 26, 35082-35093. https://doi.org/10.1007/s11356-019-06613-w

[31] Jacome, D.L.F. (2014) Caracterização física química das cinzas de palha de cana-deaçúcar através de análises térmicas simultâneas (STA). Dissertação, Campinas, São Paulo: [s.n.]. 